DOI https://doi.org/10.18551/rjoas.2017-09.06

\title{
THE STUDY OF AGRIBUSINESS WETLAND RICE FARMING SYSTEM IN AN ATTEMPT TO SYNERGIZE SUBAK WITH ECOTOURISM: A CASE IN SUBAK SEMBUNG, BALI PROVINCE OF INDONESIA
}

\author{
Arisena Gede Mekse Korri*, Dewi Ni Luh Prima Kemala \\ Agribusiness Study Program, Agriculture Faculty, Udayana University, Bali, Indonesia \\ *E-mail: arisenakorri@yahoo.co.id
}

\begin{abstract}
The rapid development of tourism in the Bali Province led to the conversion of agricultural land into a settlement and tourism support facilities are growing rapidly occurred in Denpasar City. This causes the decline in the area of rice fields and increasingly threatened the existence of subak (Balinese cultural base irrigation system for paddy fields) in Denpasar City. By making the paddy field become a tourism object based on the principles of ecotourism, is expected to maintain the existence of subak in Denpasar City. This study examines the benefits and feasibility of wetland paddy farming, economic efficiency of the use of production factors of wetland paddy farming, environmentally friendly production pattern of wetland paddy farming, the potential of subak sembung area as the attraction of ecotourism, performance of agribusiness system of wetland paddy farming and create a synergy model between subak and ecotourism based on agribusiness. The results obtained can be concluded that the commodity rice paddy worth to be used as farming in Subak Sembung, rice farmers in Subak Sembung classified as efficient in using production factors but has not achieved optimal efficiency, production patterns in Subak Sembung still using chemicals (not yet environmentally friendly) and Subak Sembung has a very noble agrarian cultural value that can be used as tourism assets.
\end{abstract}

\section{KEY WORDS}

Agribusiness, tourism, sustainable agriculture, conversion of agricultural land, agrarian cultures.

The Bali Island with an area of $5,632.86 \mathrm{~km}^{2}$ has a population of 4.15 million people, have only limited environmental resources. This large population utilizes a large enough land therefore it is estimated that land conversion will take place of 380 to 500 ha per year. In addition to population growth, the growth of the tourism support sector also contributes to the acceleration of land conversion. The most dominant sectors experiencing pressure from tourism growth are the agricultural sector (wetland and moorland).

The impact of the rapid transfer of land functions on Bali Island is the threat of food security and subak sustainability due to the increasing number of rice fields lost due to switching functions for non-agricultural use. If this does not receive serious attention from the government in the form of subsidies or protection, the destruction of the agricultural sector will lead to the destruction of the subak system which is one of the cultural heritage resources of Balinese society in the form of social institutions. Without rice fields, subak cannot exist, and without subak, the preservation of Balinese culture will be threatened. Thus the rice fields and their organizations must be conserved with various efforts.

One of the efforts that can be done to create a sustainable and firm subak in supporting the sustainable development of agriculture is to make the paddy field become tourism object based on the principles of ecotourism and supported by environmentally friendly production pattern in running rice farming.

Satria (2009), ecotourism is a concept of sustainable tourism development that aims to support the efforts of environmental conservation (nature and culture) and increase community participation in its management. Ecotourism is a tourist trip to a natural environment both natural and artificial and existing culture that is informative and participatory which aims to ensure the conservation of the natural and socio-cultural. 
Ecotourism focuses on three main things: natural or ecological sustainability, provide economic benefits, and psychologically acceptable in the social life of society. Thus, ecotourism activities directly provide access to everyone to see, to know, and enjoy the experience of nature, intellectual and local culture.

Based on the above problems it is very interesting to be studied about the utilization of subak area that conduct wetland paddy farming. This study aims to support the success of sustainable food security program and to find out how far the synergy between subak and ecotourism based on agribusiness in Denpasar City.

\section{METHODS OF RESEARCH}

Location Subak Sembung selected because Subak Sembung is a subak that still survive in the middle of Denpasar City. Population in this research is farmer/member who manage Subak Sembung in Denpasar City which amount 200 people. The sample size is $20 \%$ of the total population or about 40 people.

In this study, data collection through observation and interview. The researcher as a data collector participates in the activities that are the source of the observation. The data collected in this study is data related to farmers' income, feasibility of rice field farming, factors of production used, environmentally friendly production patterns, the potential of Subak Sembung as an attraction for ecotourism and performance of agribusiness system in Subak Sembung.

In addition to analyse descriptively, the data is processed with several variations of statistical analysis. For more detailed analysis of each of these objectives are detailed as follows. The first objective analyses the advantages and feasibility of rice farming in Subak Sembung. This objective is analysed descriptively quantitative with the calculation of cost analysis and farming income as well as the ratio analysis of revenue and cost ( $R / C$ ratio).

The second objective is to analyse the economic efficiency of the use of production factor of rice farming in Subak Sembung. To explain the amount of production and input used in the production process which is then used as the basis for calculating the efficiency of the use of production factors using the Cobb-Douglas production functionas a Frontier production function (Cobb-Douglas Production Frontier). Estimation or modelling of production function to be performed using the program of FRONTIER Version 4.1c. The Cobb-Douglas frontier stochastic production function specification is as follows.

$$
\operatorname{LnY}=\beta_{0}+\beta_{1} L n X_{1}+\beta_{2} L n X_{2}+\beta_{3} L n X_{3}+\beta_{4} L n X_{4}+\beta_{5} L n X_{5}+\beta_{6} L n X_{6}+\beta_{7} L n X_{7}+v_{i}-u_{i}
$$

Where $Y$ : rice production $(\mathrm{kg}) ; \mathrm{X}_{1}$ : land area (ha); $\mathrm{X}_{2}$ : the amount of seeds $(\mathrm{kg}) ; \mathrm{X}_{3}$ : the amount of NPK Phonska Fertilizer $(\mathrm{kg})$; $\mathrm{X}_{4}$ : the amount of Urea Fertilizer $(\mathrm{kg})$; $\mathrm{X}_{5}$ : the amount of Insecticide $(\mathrm{g}) ; \mathrm{X}_{6}$ : the amount of Herbicide $(\mathrm{g}) ; \mathrm{X}_{7}$ : the amount of labor (man days); $\mathrm{v}_{\mathrm{i}}-\mathrm{u}_{\mathrm{i}}$ : error term $\left(u_{i}\right)$ Effect of technical efficiency in the model, error term $\left(v_{i}\right)=$ noise of the expected coefficient value is $\beta_{1}-\beta_{5}>0$.

The third objective is to analyse the pattern of environmentally friendly production of wetland rice farming in Subak Sembung. This third objective is analysed descriptively qualitative to know the production pattern used is already in line with the concept of environmentally friendly. The patterns of production in this case are: the use of fertilizers, the use of pesticides and production management.

The fourth objective is to analyse the potential of Subak Sembung area as an ecotourism attraction. This fourth objective is analysed descriptively by describing condition and state of Subak Sembung. Supported with the data in the form of documentation Subak Sembung photo as authentic data. Potential Subak Sembung area should also be supported by potential data of flora, fauna, culture and human resources.

The fifth objective is to examine the performance of agribusiness system of rice farming in Subak Sembung. This objective is analysed descriptively qualitative to know the performance of agribusiness system of rice farming in Subak Sembung. The performance of agribusiness system in this case includes subsystem of supply of production facilities farming 
subsystem, marketing subsystem of agricultural products as well as price changes and external factors.

The sixth objective is to create a synergy model between subak and ecotourism based on agribusiness. In this purpose, a qualitative descriptive analysis is based on the results of one, two, three, four and five objective analysis. The sixth objective is expected to have been able to build a synergy model between subak and ecotourism based on agribusiness.

\section{RESULTS AND DISCUSSION}

According to data from farmers respondents, the amount of cash cost compared to the cost to be accounted in the activities of rice farming, because most farmers allocate costs for the payment of wages to labor outside the family which includes labor in plowing and planting activities with wholesale systems amounting to IDR1,556,393.94 man days/ha or with a percentage of $41.90 \%$. The amount of costs that must be incurred for these activities because most farmers have an advanced age,thus requires the labor to work on the land they own (Table 1).

In this research, the income on total cost is the profit obtained from rice farming in Subak Sembung. Income on total farming costs is derived from reductions in total revenues with total farming costs, thus the average income earned on total cost or average profit of IDR6,996.784.20/ha. The high income on the total cost obtained from the rice farming is because the farmers get the seed subsidyand fertilizers and farmers are not charged the tax cost for land by the government due to Subak Sembung into a green area, thus farmers are able to minimize the costs incurred in rice farming activities. Therefore, rice farming run by farmers in Subak Sembung can be said to gain profit in the growing season of July-October 2016 (Table 1).

Table 1 - Average Cost and Income of Rice Farming of Subak Sembung per Hectare per Planting Season July - October 2016

\begin{tabular}{|c|c|c|c|}
\hline Descriptions & Component of Cost & Value (IDR/Ha) & Percentage (\%) \\
\hline A. & Total Revenue & $10,711,363.64$ & - \\
\hline \multicolumn{4}{|l|}{$\begin{array}{l}\text { Cash cost } \\
\text { B. }\end{array}$} \\
\hline & - Dues for Subak & $76,909.09$ & 2.07 \\
\hline & $\begin{array}{l}\text { Sub total } \\
\text { Variable Cost }\end{array}$ & $76,909.09$ & 2.07 \\
\hline & - Seed & $29,272.73$ & 0.79 \\
\hline & - $\quad$ Fertilizer & $468,492.42$ & 12.61 \\
\hline & - $\quad$ Pesticide & $86,130.30$ & 2.32 \\
\hline & - Labor outside the family & $1,556,393.94$ & 41.90 \\
\hline & Sub total & $2,140,289.39$ & 57.62 \\
\hline & Total Cash Cost & $2,217,198.48$ & 59.69 \\
\hline \multicolumn{4}{|c|}{ Cost to be accounted } \\
\hline \multirow[t]{7}{*}{ C. } & Fixed Cost & & \\
\hline & - Depreciation of farming tools & $80,638.53$ & 2.17 \\
\hline & $\begin{array}{l}\text { Sub total } \\
\text { Variable Cost }\end{array}$ & $80,638.53$ & 2.17 \\
\hline & - Labor in the family & $1,006,060.61$ & 27.08 \\
\hline & - Ceremony & $410,681.82$ & 11.06 \\
\hline & Sub total & $1,416,742.42$ & 38.14 \\
\hline & Total Cost Accounted & $1,497,380.95$ & 40.31 \\
\hline D. & Total Cost $(B+C)$ & $3,714,597.44$ & 100.00 \\
\hline E. & Income over total costs (A-D) & $6,996,784.20$ & - \\
\hline
\end{tabular}

Wetland rice farming in Subak Sembung has an average revenue of IDR10,711,363.64/ha with a total average cost of IDR3,714,597,441/ha, then after the average revenue divided by the average total cost then it is known $R / C$ ratio on the total cost of 2.88 which means that each one rupiah(IDR1) the total cost incurred by farmers will receive revenue of IDR2.88.Thus, it can be seen that the results of $R / C$ ratio analysisof rice 
farming in Subak Sembung said feasible to be implemented in the future. The result of R/C ratio analysis of rice farming of Subak Sembung per hectare for planting season from July to October 2016 can be seen in Table 2.

Table 2 - R/C Ratio Analysis of Rice Farming of Subak Sembung per Hectare per Planting Season July - October 2016

\begin{tabular}{lll}
\hline No & Descriptions & Total (IDR/Ha) \\
\hline 1. & Revenue & $10,711,363.64$ \\
2. & Cash Cost & $2,217,198.48$ \\
3. & Cost to be accounted & $1,497,380.95$ \\
4. & Total Cost & $3,714,597.44$ \\
5. & R/C Ratioover total cost & 2.88 \\
\hline
\end{tabular}

The highest allocative efficiency value achieved by rice farmers in Subak Sembung is 1.2232 with an average of 1.0489. Farmers can be said to be efficient if they have a rating of $\geq 0.7$. The average value of the allocative efficiency indicates that rice farmers in Subak Sembung are at a price efficiency (cut-off value $\geq 0.7$ ) and farmers' opportunity to achieve the highest price efficiency was $14.25 \%$ (Table 3 ).

Farmers in Subak Sembung are on productive efficiency (technical efficiency, price efficiency, and economic efficiency) with cut-off value $\geq 0,7$; which illustrates that rice farmers are categorized as capable of utilizing production factors well, although not exactly in the frontier position (optimal production). This phenomenon occurs probably because of the subsidy from the government and channelled to Subak Sembung in the form of seed and fertilizer subsidy, thus the subsidy obtained can help in lowering farmer production costs. In addition, because Subak Sembung once won the application of rice technology, it is likely that rice paddy farmers in the area have understood how rice farming can increase production through applied technology (Table 3).

Table 3 - Efficiency Level (TE, AE, and EE)

\begin{tabular}{lllll}
\hline Efficiency Level & $\mathrm{N}$ & Minimum & Maximum & Mean \\
\hline TE & 66 & 0,8113 & 0,9997 & 0,9450 \\
AE & 66 & 0,9920 & 1,2232 & 1,0489 \\
EE & 66 & 0,9078 & 0,9994 & 0,9887 \\
\hline Valid N (list wise) & 66 & & & \\
\hline
\end{tabular}

Based on Table 4, it is concluded that all rice farmers are in technical, allocative and economic efficiency with a cut-off value of efficiency of $\geq 0.7$. Seeing from statement of Darmawan (2016) about four ways of describing the relative success of a company which in this case is the relative success of rice farmers in Subak Sembung is in the first category that is in technical and allocative efficiency.

Table 4 - Distribution of Technical, Allocative, and Economical Efficiency Levels

\begin{tabular}{llll}
\hline Efficiency Level & TE & AE & EE \\
\hline$<0,7$ & 0 & 0 & 0 \\
$\geq 0,7$ & 66 & 66 & 66 \\
\hline Total & 66 & 66 & 66 \\
\hline
\end{tabular}

Currently farmers in the Subak Sembung area is still difficult to use $100 \%$ organic fertilizer because of the dependence of farmers is still large on chemical fertilizers such as Urea, ZA, and $\mathrm{KCl}$.It takes time to convince farmers to switch to using organic fertilizer.Farmers use chemical fertilizers in excess without being balanced with other fertilizers, such as organic fertilizer.The use of chemical fertilizers and pesticides makes soil fertility reduced so that every growing season comes, the need for fertilizers and pesticides to be met by farmers continues to increase.The increasing need for fertilizers and chemical pesticides causes the farmers to incur greater costs, thus the income received by farmers is decrease. This increase in cost is not only due to the increasing amount of use, but also due 
to the increasingly expensive price of fertilizers and chemical pesticidesand more difficult to obtain. This condition can threaten the continuity of farming.

Subak Sembung as ecotourism area, causing farming in Subak Sembung has selling value as a tourist attraction for the visitors. The establishment of ecotourism area is useful to increase the economic value for the parties involved in the management,and add environmental value to conserve the Subak Sembung area in order to remain sustainable.In achieving the objectives of the development of Subak Sembung ecotourism, ecotourism managers certainly involve the parties who are in the ecotourism area. Parties referred to in this case are the people who are in Peguyangan Village, as well as farmers who run the farm in Subak Sembung area.The involvement in this regard is to make them as partners in the effort of developing ecotourism area. In the implementation of programs that have been packaged in the form of tour packages, the manager of ecotourism will involve the community around the subak area and the farmers who run the farm in Subak Sembung.

Subak Sembung as an ecotourism area is also rich with agricultural culture.But the agricultural potential has not been maximally worked out to be a tourism product.Because the true life of agriculture has enriched the culture that is now sold as a tourist product.However, agricultural culture has not become a superior product that is marketed to tourists. In some places have been able to create attractions based on agriculture (agrotourism), or ecotourism.As in Subak Jati Luwih, Tabanan, subak area is able to become a tourist attraction.

In the upstream agro-industry subsystem on rice farming in Subak Sembung, according to farmer respondents, the procurement of seed production facilities for rice farming in Subak Sembung obtained through preparationof The List of Proposed Purchase Subsidized Seeds (DUPBB) according to the needs of the seeds of each farmer. Preparation of DUPBB aims to reduce the production costs incurred by farmers in rice farming activities through seed subsidy fromDepartment of Agriculture Food Crops and Horticulture Denpasar City. In rice farming in Subak Sembung, the assistance of the subsidized seeds is not given fully to the farmers because there is free seed assistance to be given to farmers by the Department of Agriculture Food Crops and Horticulture Denpasar City. The goal is to break the chain of pests and diseases that generally attack rice plants, in order to maintain the amount of rice production obtained by farmers.

Downstream agro-industry subsystem is an activity in the farm which includes postharvest processing as well as marketing of production. Based on the respondents of farmers in Subak Sembung, they do not do post-harvest processing on the crop. This is because farmers already sell paddy with slash system, thus in the subsystem of downstream agroindustry only discussed about marketing channel from paddy that produced at its farm in Subak Sembung.

Each type of agricultural commodity has different marketing channels between each other. All respondents of rice farmers in Subak Sembung, amounting to 66 people selling their products using slash system. The slash system actor usually goes directly to the farmers on the paddy fields they own. The slash system used by farmers in wetland rice marketing is caused by farmers having difficulty in finding labor in Denpasar City area for harvesting of production,considering the majority of rice farmers in Subak Sembung already in the elderly. In addition, farmers use the system because they want to be more practical to take care of the crop that is generally time consumingand requires a large place to dry the crop. Usually with this slash system, it can be settled quickly so that the farmer's land can be replanted immediately.

In this slashsystem, of course there are advantages and disadvantages received by farmers. The advantages of slash system for farmers in Subak Sembung are farmers become easier in harvesting and marketing their production, while the Idisadvantages are the farmers do not know the maximum revenue obtained from the production of rice each season planting.

Based on the observations and has been described previously built a model of synergy between subak and ecotourism based on agribusiness. The development of ecotourism in Subak Sembung is one of the efforts to increase the natural resources potential,environment 
and uniqueness of nature and culture that will later become one of the leading sectors of the region that has not been developed optimally. Where ecotourism is a natural tourism activity with attention to elements of education, understanding and support for natural resource conservation efforts. With the principle of conservation development that protects, preserves and utilizes sustainably existing natural resources and does not escape from economic value, educationas well as community participation in the planning, utilization and control of ecotourism with socio-cultural values.

In accordance with the objectives of this research are to support the success of sustainable food security program and create synergy between subak and ecotourism based on agribusiness, then formed a model of synergy between subak and ecotourism based on agribusiness.

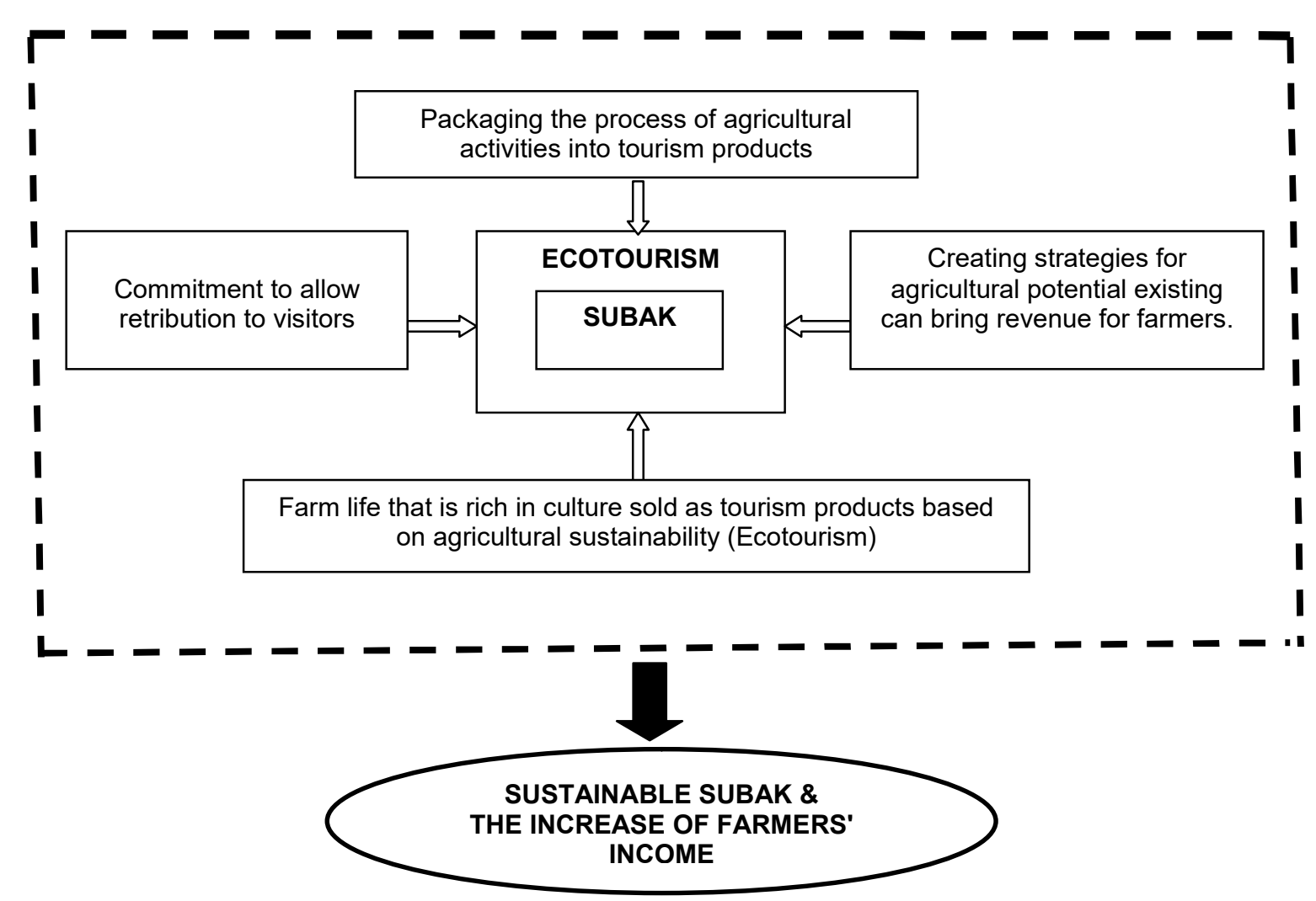

Figure 1 - Synergy Model between Subak and Ecotourism Based on Agribusiness

The development of alternative tourism objects such as ecotourism requires a touch of creativity and a new breakthrough, thus its presence can draw from existing objects so far. The development of alternative tourism objects such as ecotourism should remain based on local culture.Rice fields and farmers become one of tourism assets. From agriculture life has born the values of agrarian culture which very noble and can be used as tourism assets.Local wisdom that becomes the power of subak has a basic nature of socioculturaland unique socio-religious.

Subak that have various intelligences that are part of the local culture based on the concept of Tri Hita Karanaand received a universal appreciation associated with the philosophical content of the cosmos. The essence of local wisdom is a high commitment to the sustainability of nature, human subjectivity, religious sense and construction of reasoning that empathize with the offerings, togetherness, harmony and the balance of sustainable universe.

Integrating the agricultural sector with tourism will have a broad impact that increases farmers' income. Preserve the culture of agriculture, providing an alternative tourism object that may never be found in other countries.In terms of agricultural empowerment to support 
the tourism sector is very strategic. From the agricultural production side, the process of agricultural activities can also be packaged into tourism products. Then the agricultural ritual is also very rich and interesting for tourism. But it needs to be packaged and need strategies thus agricultural potential it can bring in income.

\section{CONCLUSION}

Between the upstream agro-industry subsystem, farming subsystem, subsystems of downstream and agro-industries subsystems of supporting institutions have been running quite well, but still needs further improvement. Subak Sembung has a very noble agrarian cultural value that can be used as tourism assets. Related to the ecotourism area in Subak Sembung there is a special support institution in the form of ecotourism management. Development of ecotourism in Subak Sembung shows that the results obtained from the involvement of farmers in ecotourism activities cannot be felt directly but enter into a typical organization of Subak Sembung, even though the paddy farmers are still benefiting.

\section{REFERENCES}

1. Adiyoga, Witono. 1999. Beberapa Alternatif Pendekatan untuk Mengukur Efisiensi atau In-Efisiensi dalam Usahatani. http://www.litbang.pertanian.go.id/warta-ip/pdffile/witono.pdf. Diunduh pada tanggal 3 Januari 2017

2. Badan Pusat Statistik Propinsi Bali. 2016. Propinsi Bali Dalam Angka. Bali Province in Figures 2016. CV. Bhinneka: Denpasar.

3. Darmawan, Dwi Putra. 2016. Pengukuran Efisiensi Produktif Menggunakan Pendekatan Stochastic Frontier. New Elmatera Publisher : Yogyakarta

4. Desa Peguyangan. 2015. Profil dan Potensi Desa Peguyangan. Tidak diterbitkan: Denpasar.

5. Fandeli, Chafid. 2000. Pengertian dan Konsep Ekowisata. Jurnal. Fakultas Kehutanan. Universitas Gadjah Mada: Yogyakarta.http://saveforest.webs.com/konsep_ekowisata.pdf. Diakses pada tanggal 21 November 2016.

6. Hadi, S. P. 2007. Pariwisata Berkelanjutan (Sustainable Tourism). Makalah Seminar Sosialisasi Sadar Wisata Edukasi Sadar Wisata bagi Masyarakat di Semarang.

7. Pitana, Gde dan Setiawan AP., Gede. 2004. Revitalisasi Subak dalam Memasuki Era Globalisasi. Andi: Yogyakarta.

8. Satria, D.2009. Strategi Pengembangan Ekowisata Berbasis Ekonomi Lokal Dalam Rangka Program Pengentasan Kemiskinan Di Wilayah Kabupaten Malang. Journal of Indonesian Applied Economics. Vol. 3 No. 1: 37-47

9. Sumiyati, Sutiarso,L., Windia,W., Sudira,P. 2011. Evaluasi Kinerja Fisik Sistem Subakyang Berorientasi Agroekowisata Menggunakan Pendekatan Logika Fuzzy. Jurnal Teknik Industri, Vol. 12, No. 2, Agustus 2011: 147-155.

10. Sutawan, N. 2001. Eksistensi Subak di Bali:Mampukah bertahan Menghadapi Berbagai Tantangan. Jurusan Sosial Ekonomi Pertanian Fakultas Pertanian Udayana. Denpasar.

11. Suyastiri, N.M.2012. Pemberdayaan Subak Melalui "Green Tourism" Mendukung Keberlanjutan Pembangunan Pertanian Di Bali. Journal SEPA : Vol. 8 No. 2 Pebruari 2012: $51-182$

12. Widowati, S.2012. Kajian Potensi dan Evaluasi Penerapan Prinsip - Prinsip dan Kriteria Ekowisata di Kawasan Taman Wisata Alam Kawah ljen, Desa Taman Sari, Kabupaten Banyuwangi. Tesis. Program Pascasarjana Universitas Udayana Denpasar

13. Windia, Wayan. 2006. Transformasi Sistem Irigasi Subak yang Berlandaskan Konsep Tri Hita Karana. PT. Offset BP Denpasar: Jakarta. 